\title{
Correlation between Serum Enzymes, Isozyme Patterns and Histologically Detectable Organ Damage*
}

\author{
H. C. Grice, $†$ M. L. Barth, H. H. Cornish, G. V. Foster and R. H. Gray \\ Department of Environmental and Industrial Health, School of Public Health, \\ The University of Michigan, Ann Arbor, Michigan 48104, USA
}

(Received 20 April 1971)

\begin{abstract}
Serum enzyme levels and isozyme profile were utilized as a measure of hepatotoxic response to carbon tetrachloride, mercuric chloride, diethanolamine and thioacetamide. The sensitivity of these measurements was compared with the degree of morphological damage to the liver or kidney as assessed by light and electron microscopy. Morphological damage was present at dosage levels considerably below those necessary to induce detectable enzyme alterations. Generally, advanced degenerative change, including necrosis, had occurred in both the liver and kidney before enzyme alterations were seen.
\end{abstract}

\section{INTRODUCTION}

Serum enzyme levels have been utilized for a number of years as a measure of hepatotoxic response to chemical compounds and as diagnostic aids in animals and man. Koch-Weser, Farber \& Popper (1951) studied the histological and functional alterations, including tissue enzyme levels, in rats treated with ethionine or carbon tetrachloride $\left(\mathrm{CCl}_{4}\right)$. A single relatively large dose of $3.0 \mathrm{ml} \mathrm{CCl} / \mathrm{kg}$ body weight was used in those studies. Liver alkaline phosphatase increased and non-specific esterase activity decreased in $\mathrm{CCl}_{4}$-treated animals; the changes correlated with the development of necrosis in the liver. Balazs, Murray, McLaughlan \& Grice (1961) compared the ability of a number of liver function tests, including serum glutamic-pyruvic transaminase (SGPT) to detect early organ damage induced by a number of toxic agents. Klaassen \& Plaa (1967) studied the relative effects of a number of chlorinated hydrocarbons on liver and kidney function in the dog, utilizing SGPT as one measure of hepatotoxicity.

In addition to serum enzyme levels, serum isozyme patterns have more recently been utilized for the detection of organ damage in experimental animals (Reeves, Busby \& Scotti, 1966; Cornish, Barth \& Dodson, 1970). Serum isozyme patterns are particularly useful in that the target organ can be ascertained, dose response curves developed and induction time in the development of organ damage studied. Furthermore, in some instances they may be used to demonstrate early tissue damage before morphological change is discernible by routine histological techniques. In addition, they have the distinct advantage of allowing

*This study was supported in part by research grants ES-00339 and GM-12854 from the National Institutes of Health and by General Research Support Grant, Project 112, School of Public Health, The University of Michigan.

†On leave from Research Laboratories, Food and Drug Directorate, Department of National Health and Welfare, Tunney's Pasture, Ottawa 3, Canada, to which address correspondence should be directed. 
assessment of pathological effects without necessitating biopsy procedures or the sacrifice of valuable test animals.

When isozyme profiles are used for these purposes, it is necessary to know the degree of morphological damage associated with alterations in the patterns. This report presents findings related to the sensitivity of serum enzymes and isozyme patterns in detecting organ damage. In these studies, the degree of morphological damage was assessed by light and electron microscopy (EM). The changes observed were correlated with alterations in total serum enzyme activity and isozyme profiles.

\section{EXPERIMENTAL}

Animals and diet. Male Sprague-Dawley rats weighing 225-300 g were used in these studies. They were maintained on a diet of commercial rat pellets (Rockland Mouse and Rat Diet, from Teklad, Inc., Monmouth, IIl.) and water given ad lib.

\section{Test materials and dosage schedules}

The doses of the various compounds used to produce toxic effects were selected to induce either minimal or pronounced tissue damage. $\mathrm{CCl}_{4}$, mercuric chloride $\left(\mathrm{HgCl}_{2}\right)$ and diethanolamine (DEA) were injected intraperitoneally, and thioacetamide (TA) was given orally to induce liver and/or kidney damage.

$\mathrm{CCl}_{4}$. A $3 \%$ solution of $\mathrm{CCl}_{4}$ in peanut oil was injected at dose levels of 0.03 and $0.06 \mathrm{ml}$ $\mathrm{CCl}_{4} / \mathrm{kg}$, while a $10 \%$ solution was used for doses of 0.1 and $0.2 \mathrm{ml} \mathrm{CCl} / \mathrm{kg}$. Six animals were used for each dosage level and six control animals were given only peanut oil. Animals given 0.1 or $0.2 \mathrm{ml} / \mathrm{kg}$ were fasted between the time of dosing and sacrifice. All rats were killed $24 \mathrm{hr}$ after injection.

$\mathrm{HgCl}_{2}$. A $0.2 \%$ solution of $\mathrm{HgCl}_{2}$ in water was injected at levels of $0.1,0.5$ and $2.0 \mathrm{mg} / \mathrm{kg}$. Six animals were used for each group and for a control group treated with water only. The animals were killed $24 \mathrm{hr}$ after injection.

$D E A$. DEA neutralized with $\mathrm{HCl}(28.4 \%$ DEA) was injected at levels of 500 and 100 $\mathrm{mg} / \mathrm{kg}$, calculated as the free base, to groups of six rats. Rats were fasted after dosing and sacrificed 4 or $24 \mathrm{hr}$ later. A control group was given water only. Enzyme studies and histology were carried out on all rats.

$T A$. Doses of 20 and $50 \mathrm{mg} \mathrm{TA} / \mathrm{kg}$ in a $1 \%$ aqueous solution were given orally to rats and the animals were sacrificed $24 \mathrm{hr}$ later. A time-sequence study was also carried out, in which eight groups each of three rats were given $200 \mathrm{mg} \mathrm{TA} / \mathrm{kg}$ in a $10 \%$ solution and sacrificed $1,2,4,8,12,24,48$ and $72 \mathrm{hr}$ later. Control groups were given water only. Total serum lactic dehydrogenase (LDH) activity and isozyme patterns were determined and histological sections were prepared on all animals. Serum glutamic-oxalacetic transaminase (GOT) activity was determined only in rats given the lower doses.

\section{Tissue and enzyme studies}

Tissues for histological examination were fixed in buffered neutral formalin and prepared using standard techniques. Tissues for EM were fixed for $2 \mathrm{hr}$ with $3 \%$ glutaraldehyde in $0.1 \mathrm{M}$-phosphate buffer, and post-fixed with $2 \%$ osmium tetroxide in $0.1 \mathrm{M}$-phosphate buffer. The tissues were embedded in Epon resin and sections were post-stained with uranyl magnesium acetate and lead citrate. Examination by EM was reserved for those instances where only borderline or negative results were obtained with the light microscope. 
Total serum LDH and GOT were determined spectrophotometrically according to the method of Wróblewski \& LaDue (1955) and Karmen (1955), respectively. One unit of activity is that amount of enzyme which will cause a decrease in $O D_{340}$ of $0.001 / \mathrm{min}$ at $25^{\circ} \mathrm{C}$. LDH zymograms were made using vertical polyacrylamide-gel electrophoresis as previously described by Cornish et al. (1970).

\section{RESULTS}

Carbon tetrachloride injury was detected histologically at the $0.03 \mathrm{ml} / \mathrm{kg}$ level and consisted of loss of basophilic staining of the cytoplasm and vacuolation of hepatic parenchymal cells in the central vein areas (Fig. 1). Fat was also observed in these areas in the sections stained with Oil Red O. EM examination showed distortion and dilation of rough endoplasmic reticulum with some loss of ribosomes from the reticulum (Fig. 2). Mitochondria of the treated animals appeared less dense than controls and occurred in unusual shapes. Despite this degree of histological and ultrastructural change, total serum LDH and GOT values were within normal limits. These and subsequent serum enzyme levels are recorded in Table 1 . The histological and ultrastructural changes were slightly more advanced at the $0.06-\mathrm{ml} / \mathrm{kg}$ level and abundant fat was seen around the central veins (Fig. 3). LDH and GOT values were still within normal ranges. At the $0 \cdot 1-\mathrm{ml} / \mathrm{kg}$ level, marked fatty change was seen in the liver cells, necrotic cells were in evidence and focal collections of mononuclear cells were seen. LDH levels were normal but GOT was increased by approximately $12 \%$. At the $0.2-\mathrm{ml} / \mathrm{kg}$ level, extensive hepatic parenchymal damage was seen (Fig. 4). This degree of damage was associated with GOT values increased to about four times the normal. The isozyme profiles for rats given 0.1 or $0.2 \mathrm{ml} \mathrm{CCl}_{4} / \mathrm{kg}$ are shown in Fig. 5 . Elevated LDH-5 levels were evident only at the highest dose.

In $\mathrm{HgCl}_{2}$-injected animals morphological change was evident in the kidney well in advance of changes in LDH isozyme patterns. A dose of $2 \mathrm{mg} / \mathrm{kg}$ resulted in an increase in total serum LDH (Table 1) and a marked increase in LDH-1 and LDH-2, characteristic of kidney damage (Fig. 6). Marked tubular necrosis with exfoliation of tubular epithelial cells and subsequent tubular cast formation was evident at the lower dose level of $0.5 \mathrm{mg} / \mathrm{kg}$ (Fig. 7).

Vacuolization of liver-cell cytoplasm (Fig. 8) and cytoplasmic basophilia were seen histologically $4 \mathrm{hr}$ after administration of DEA at levels of 100 and $500 \mathrm{mg} / \mathrm{kg}$, respectively (Fig. 8). At both dose levels, ultrastructural changes, also characterized by cytoplasmic vacuolization, were observed $4 \mathrm{hr}$ after injection (Fig. 9). Regions of stacked smooth membranes occurred around the periphery of the vacuoles, a finding taken to indicate the rapid formation of the vacuole (Fig. 10). Mitochondria of the hepatocytes appeared swollen and less dense in the experimental than in control animals. At $24 \mathrm{hr}$ there was marked vacuolation or rarefaction of the cytoplasm of the liver cells. The cytoplasm was clumped and tended to aggregate in the periphery of the cell. The nuclei were more deeply basophilic than normal and nucleoli were prominent. All liver cells seemed affected but no necrotic cells were seen. Other histological changes seen at 4 and $24 \mathrm{hr}$ after administration of 500 $\mathrm{mg} \mathrm{DEA} / \mathrm{kg}$ included tubular degeneration, affecting principally the epithelial cells of the proximal convoluted tubules. Occasional cells were necrotic and acidophilic cast material was present in the lumen in some cases. There was also vacuolation and rarefaction of the cytoplasm of the renal tubular epithelium. The changes were observed to a lesser degree at $100 \mathrm{mg} / \mathrm{kg}$. Elevation in serum $\mathrm{LDH}$ was seen only with $500 \mathrm{mg} / \mathrm{kg}$ at 4 and $24 \mathrm{hr}$ after 
Table 1. Serum enzyme levels in rats after treatment with $\mathrm{CCl}_{4}, \mathrm{HgCl}_{2}, \mathrm{TA}$ and $\mathrm{DEA}$

\begin{tabular}{|c|c|c|c|c|c|}
\hline \multirow[b]{2}{*}{ Compound } & \multirow{2}{*}{$\begin{array}{c}\text { Dose } \\
(\mathrm{mg} / \mathrm{kg})^{*}\end{array}$} & \multirow{2}{*}{$\begin{array}{c}\text { Group } \\
\text { size }\end{array}$} & \multirow{2}{*}{$\begin{array}{l}\text { Time of } \\
\text { sacrifice } \\
\text { (hr after } \\
\text { treatment) }\end{array}$} & \multicolumn{2}{|c|}{ Activity $†$ (units/ml) } \\
\hline & & & & $\mathrm{LDH}$ & GOT \\
\hline \multirow[t]{2}{*}{$\mathrm{CCL}_{4}$} & $\begin{array}{l}0 \text { (control) } \\
0.03 \\
0.06\end{array}$ & $\begin{array}{l}6 \\
6 \\
6\end{array}$ & $\begin{array}{l}24 \\
24\end{array}$ & $\begin{array}{c}761 \pm 58 \\
1010 \pm 156 \\
1101 \pm 115\end{array}$ & $\begin{array}{l}36 \pm 2 \\
36 \pm 2 \\
42 \pm 2\end{array}$ \\
\hline & $\begin{array}{l}0 \text { (control) } \\
0 \cdot 1 \\
0 \cdot 2\end{array}$ & $\begin{array}{l}6 \\
6 \\
6\end{array}$ & $\begin{array}{l}24 \\
24\end{array}$ & $\begin{array}{c}1183 \pm 108 \\
965 \pm 51 \\
1429 \pm 205\end{array}$ & $\begin{array}{c}40 \pm 3 \\
53 \pm 2 \\
185 \pm 47\end{array}$ \\
\hline \multirow[t]{2}{*}{$\mathrm{HgCl}_{2}$} & $\begin{array}{l}0 \text { (control) } \\
0.1 \\
0.5\end{array}$ & $\begin{array}{l}6 \\
6 \\
6\end{array}$ & $\begin{array}{l}24 \\
24\end{array}$ & $\begin{array}{c}1062 \pm 172 \\
1056 \pm 230 \\
649 \pm 85\end{array}$ & $\begin{array}{l}37 \pm 2 \\
32 \pm 2 \\
33 \pm 2\end{array}$ \\
\hline & $\begin{array}{l}0 \text { (control) } \\
2 \cdot 0\end{array}$ & $\begin{array}{l}6 \\
6\end{array}$ & 24 & $\begin{array}{r}324 \pm 94 \\
1062 \pm 69\end{array}$ & - \\
\hline DEA & $\begin{array}{l}0 \text { (control) } \\
100 \\
500\end{array}$ & $\begin{array}{l}6 \\
3 \\
3 \\
3 \\
3\end{array}$ & $\begin{array}{l}4 \\
24 \\
4 \\
24\end{array}$ & $\begin{array}{l}313 \pm 56 \\
208 \pm 43 \\
138 \pm 30 \\
700 \pm 84 \\
600 \pm 146\end{array}$ & $\begin{array}{c}36 \pm 2 \\
50 \pm 6 \\
46 \pm 2 \\
122 \pm 23 \\
96 \pm 14\end{array}$ \\
\hline \multirow[t]{2}{*}{ TA } & $\begin{array}{l}0 \text { (control) } \\
20 \\
50\end{array}$ & $\begin{array}{l}6 \\
6 \\
6\end{array}$ & $\begin{array}{l}24 \\
24\end{array}$ & $\begin{array}{c}655 \pm 46 \\
309 \pm 18 \\
1508 \pm 221\end{array}$ & $\begin{array}{c}42 \pm 1 \\
41 \pm 1 \\
280 \pm 53\end{array}$ \\
\hline & $\begin{array}{l}0 \text { (control) } \\
200\end{array}$ & $\begin{array}{l}3 \\
3 \\
3 \\
3 \\
3 \\
3 \\
3 \\
3 \\
3\end{array}$ & $\begin{array}{l}1 \\
2 \\
4 \\
8 \\
12 \\
24 \\
48 \\
72\end{array}$ & $\begin{array}{c}2123 \pm 288 \\
1447 \pm 333 \\
1840 \pm 104 \\
1453 \pm 90 \\
2250 \pm 509 \\
2367 \pm 419 \\
23367 \pm 2866 \\
1730 \pm 65 \\
913 \pm 189\end{array}$ & \\
\hline
\end{tabular}

*Doses of $\mathrm{CCl}_{4}$ are expressed in $\mathrm{ml} / \mathrm{kg}$.

$\nmid$ Values are means \pm SEM for the numbers of animals stated.

dosing. Serum GOT levels were elevated at 4 and $24 \mathrm{hr}$ after $500 \mathrm{mg} \mathrm{DEA} / \mathrm{kg}$, but the changes were only borderline at $100 \mathrm{mg} / \mathrm{kg}$. LDH zymograms at $4 \mathrm{hr}$ indicated differences from controls at $500 \mathrm{mg} / \mathrm{kg}$ but not at $100 \mathrm{mg} / \mathrm{kg}$ (Fig. 11).

With TA there was evidence of histological damage at $20 \mathrm{mg} / \mathrm{kg}$ although this dose did not increase serum enzymes (Table 1) or LDH isozymes. At $50 \mathrm{mg} / \mathrm{kg}$ there was a marked increase in serum LDH and GOT (Table 1) and a broadening of LDH-5 (Fig. 12).

The results of the time-sequence study with TA are also summarized in Table 1. Mean LDH values were ten times the normal at $24 \mathrm{hr}$, but at $48 \mathrm{hr}$ were within the normal range. The isozyme patterns paralleled these changes, showing considerable elevation and broadening of LDH-5 (Fig. 13). At $48 \mathrm{hr}$, some evidence of damage was still apparent from the isozyme patterns, although total LDH had returned to normal. Cell damage in the liver was prominent and extended beyond these time intervals to $72 \mathrm{hr}$, by which time serum 


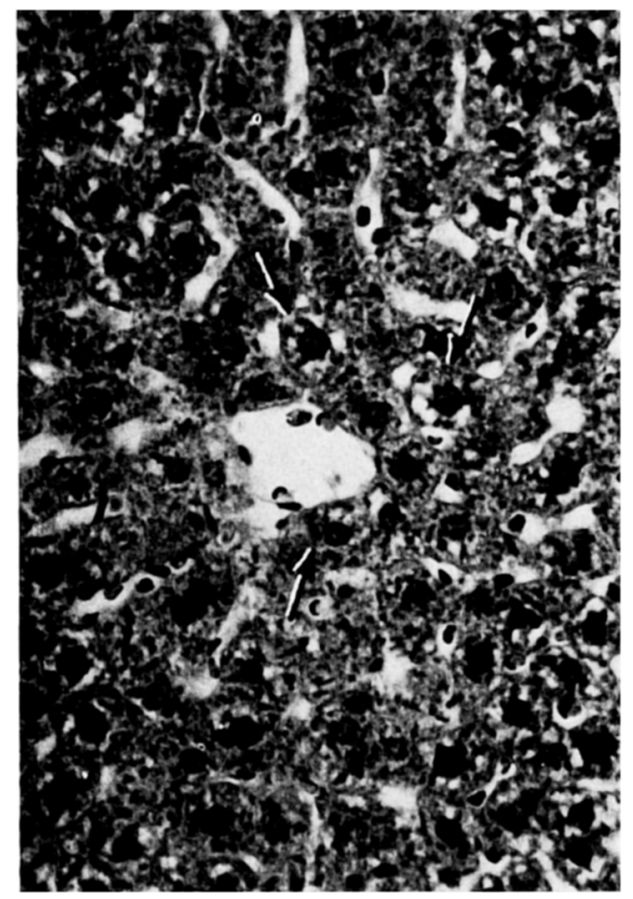

FIG. 1. Photomicrograph of liver from a rat given $0.03 \mathrm{ml} \mathrm{CCl}_{4} / \mathrm{kg}$ and killed $24 \mathrm{hr}$ later, showing vacuolation of cells in the centrilobular area (arrowed) and a loss of cytoplasmic basophilia. This is considered to be a minimal change. Haematoxylin and eosin $\cdot 445$.

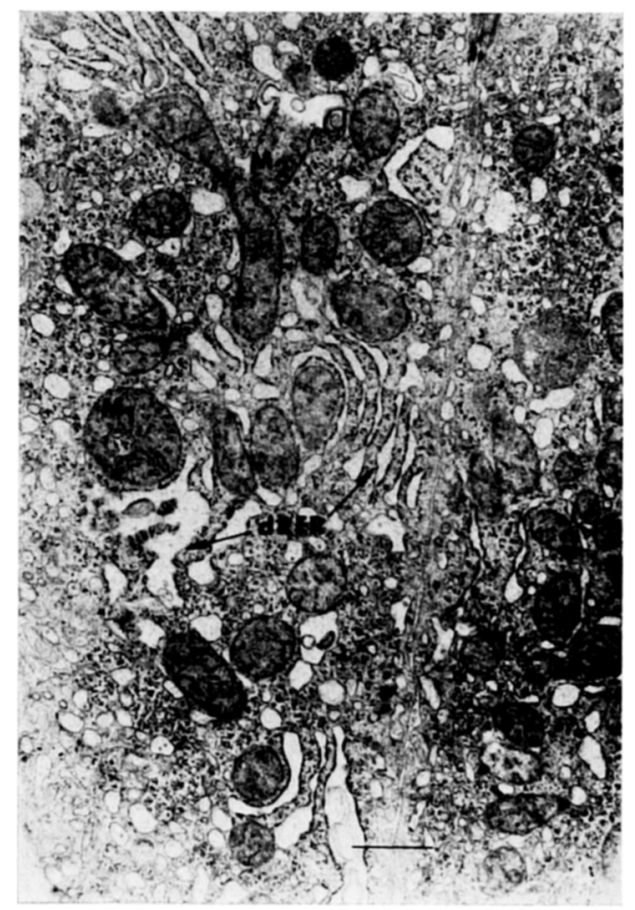

FIG. 2. Electronmicrograph from the liver of a rat given $0.03 \mathrm{ml} \mathrm{CCl} / \mathrm{kg}$ and killed $24 \mathrm{hr}$ later showing cytoplasmic abnormalities, including dilated rough endoplasmic reticulum (dRER) and mitochondria, which are irregularly shaped $\left(M_{1}\right)$ and undergoing degeneration $\left(M_{2}\right) . \times 15,700$. 


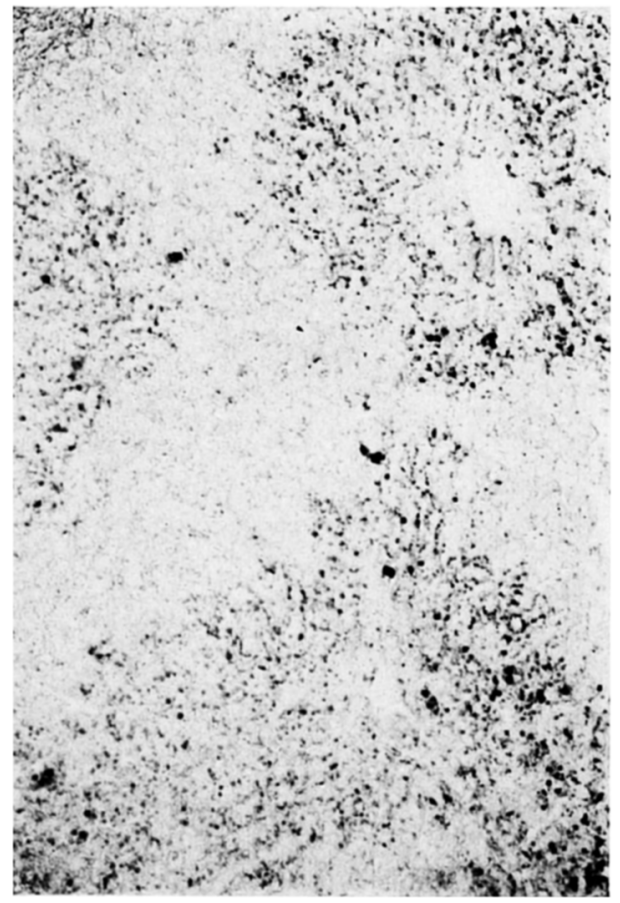

Fig. 3. Photomicrograph of liver from a rat given $0.06 \mathrm{ml} / \mathrm{kg} \mathrm{CCl}_{4}$ and killed $24 \mathrm{hr}$ later. There is abundant fat in cells around the centrilobular areas. Oil Red $\mathrm{O} \times 50$.

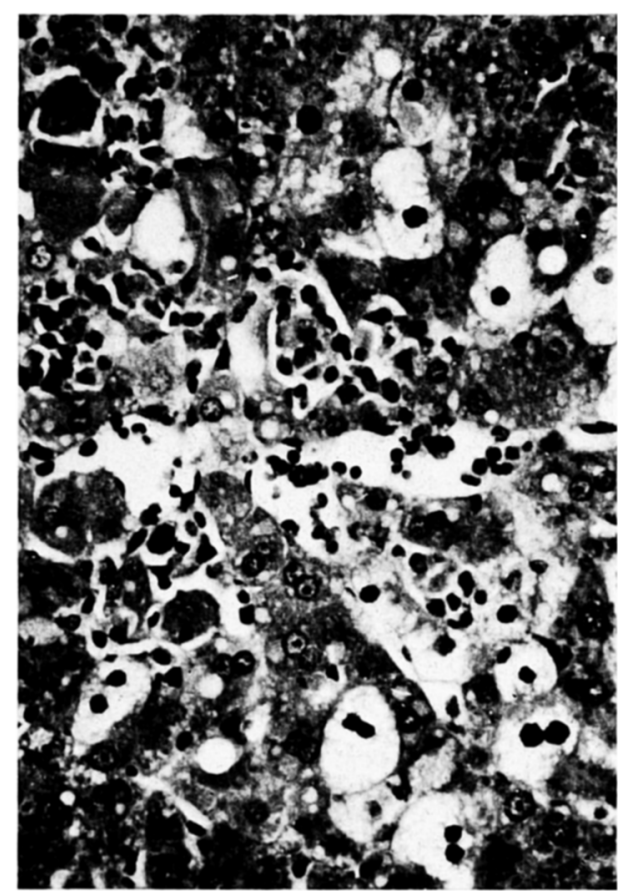

FIG. 4. Photomicrograph of liver from a rat given $0.2 \mathrm{ml} \mathrm{CCl} / \mathrm{kg}$ and killed $24 \mathrm{hr}$ later. There is extensive hepatic parenchymal damage and some cellular infiltration. Haematoxylin and eosin $\times 356$. 


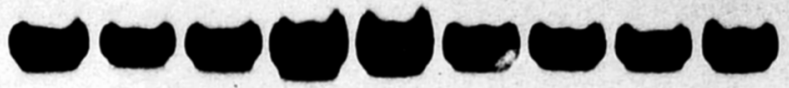
C C
C
0.20 .2
0.2
0.10 .1
0.1

FIG. 5. LDH zymogram from rats killed $24 \mathrm{hr}$ after $\mathrm{CCl}_{4}$ administration. The dose (in $\mathrm{ml} / \mathrm{kg}$ ) is indicated at the bottom of each channel. Control rats are indicated by the letter $C$. Two of the rats given $0.2 \mathrm{ml} / \mathrm{kg}$ have LDH-5 bands which are heavier than any of the controls, suggesting liver damage.

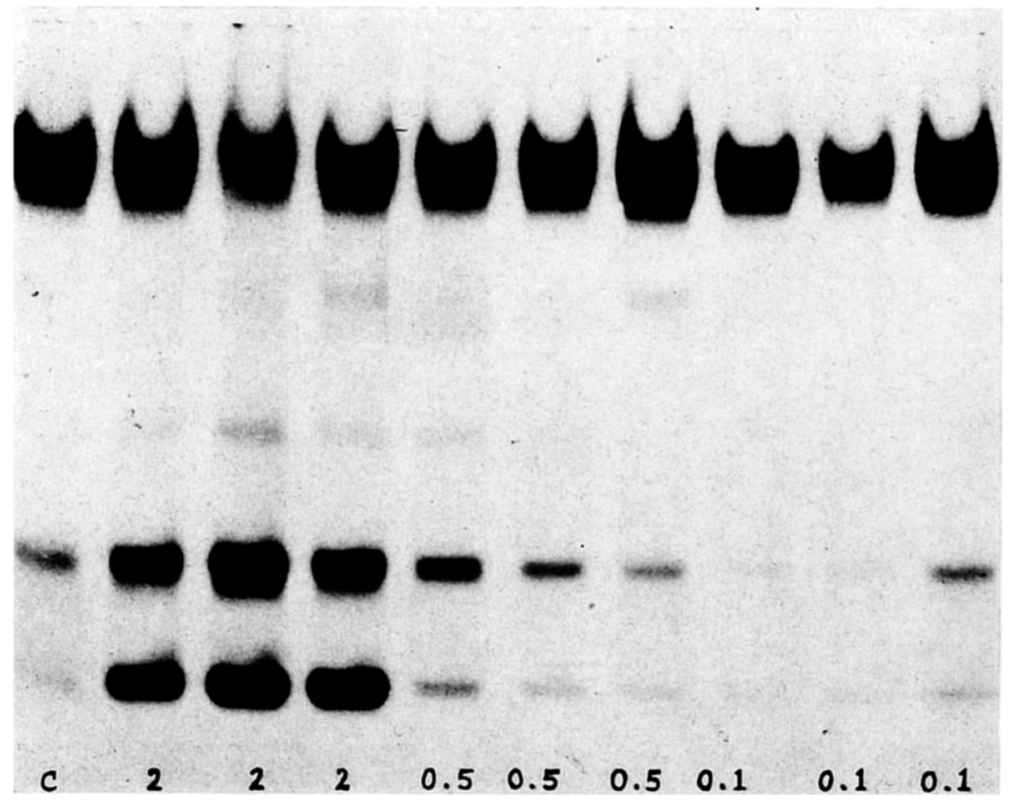

FIG. 6. $\mathrm{LDH}$ zymogram from rats killed $24 \mathrm{hr}$ after treatment with $\mathrm{HgCl}_{2}$. The dose (in $\mathrm{mg} / \mathrm{kg}$ ) is indicated at the bottom of each channel. The rats given $2 \mathrm{mg} / \mathrm{kg}$ show elevations in the activity of LDH bands 1 and 2, characteristic of kidney damage. 


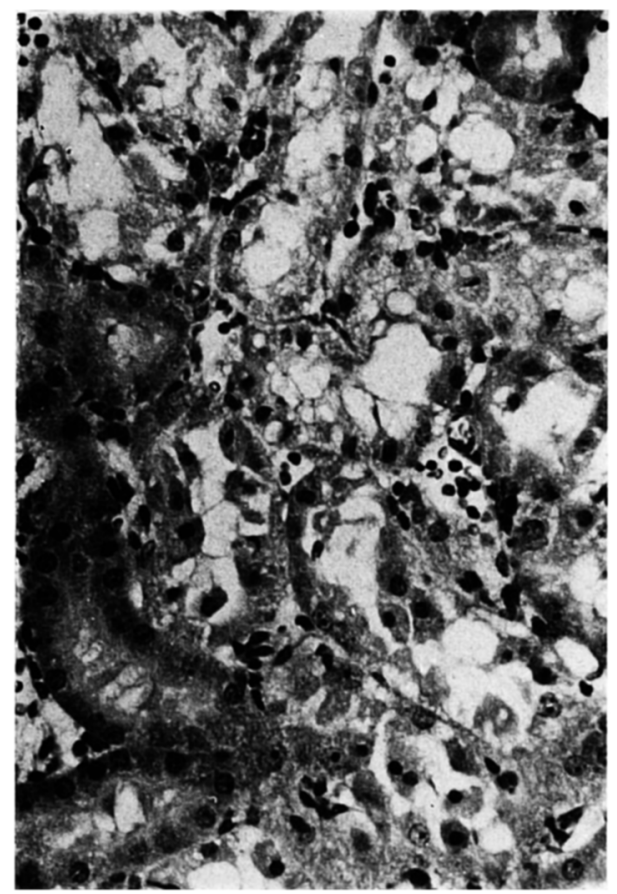

Fig. 7. Photomicrograph of kidney from a rat given $0.5 \mathrm{mg} \mathrm{HgCl} / \mathrm{kg}$ and killed $24 \mathrm{hr}$ later. Necrosis of the tubular epithelial cells is marked. Haematoxylin and eosin $\times 570$.

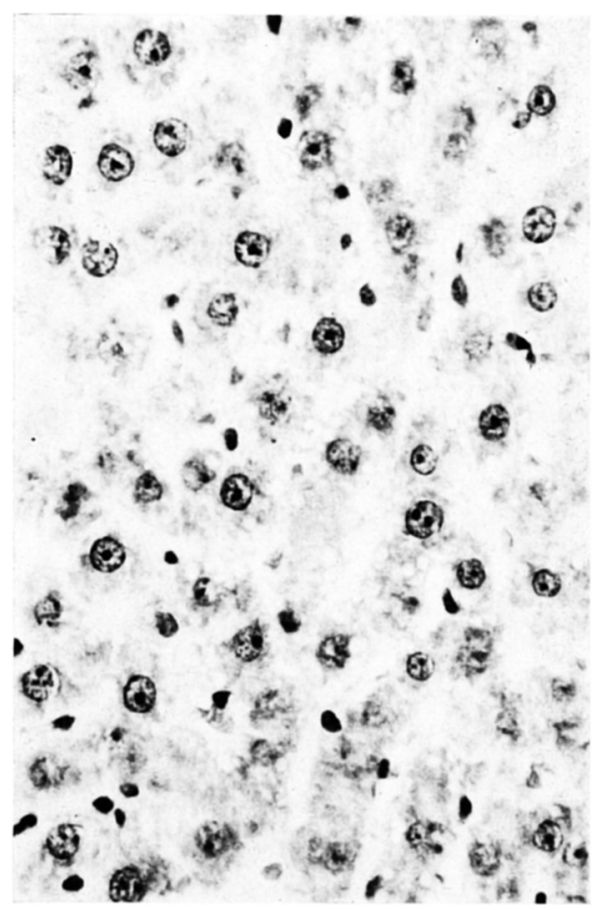

FIG. 8. Photomicrograph of liver from a rat given $100 \mathrm{mg} \mathrm{DEA} / \mathrm{kg}$ and killed $4 \mathrm{hr}$ later. There is marked vacuolization of hepatocytes. $\times 500$ 


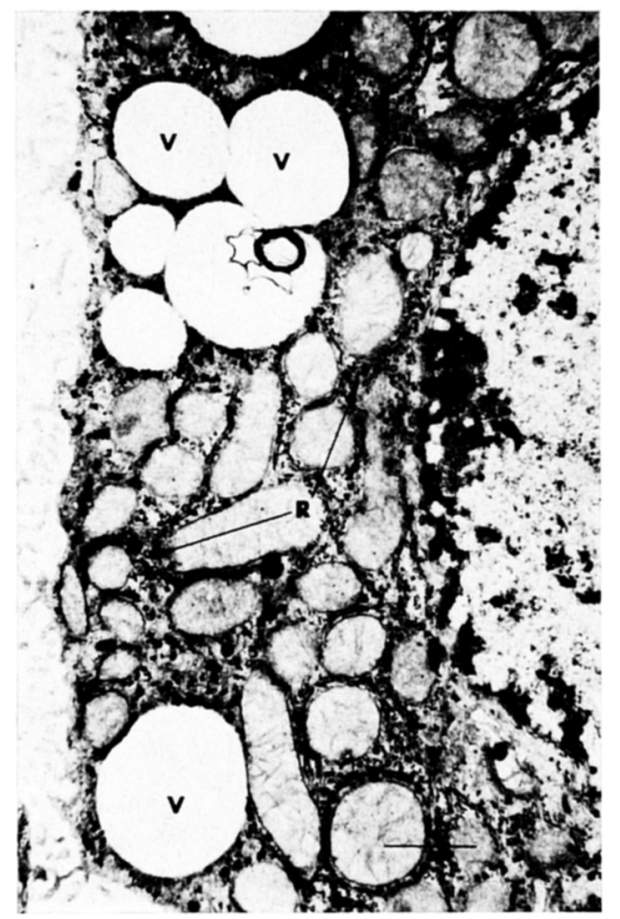

FIG. 9. Electronmicrograph of liver from a rat given $100 \mathrm{mg} \mathrm{DEA} / \mathrm{kg}$ and killed $4 \mathrm{hr}$ later. A hepatocyte near a central vein region has an accumulation of vacuoles $(V)$ adjacent to the cell periphery. Areas of free ribosomes (R) are frequently observed. $\times 17,300$.

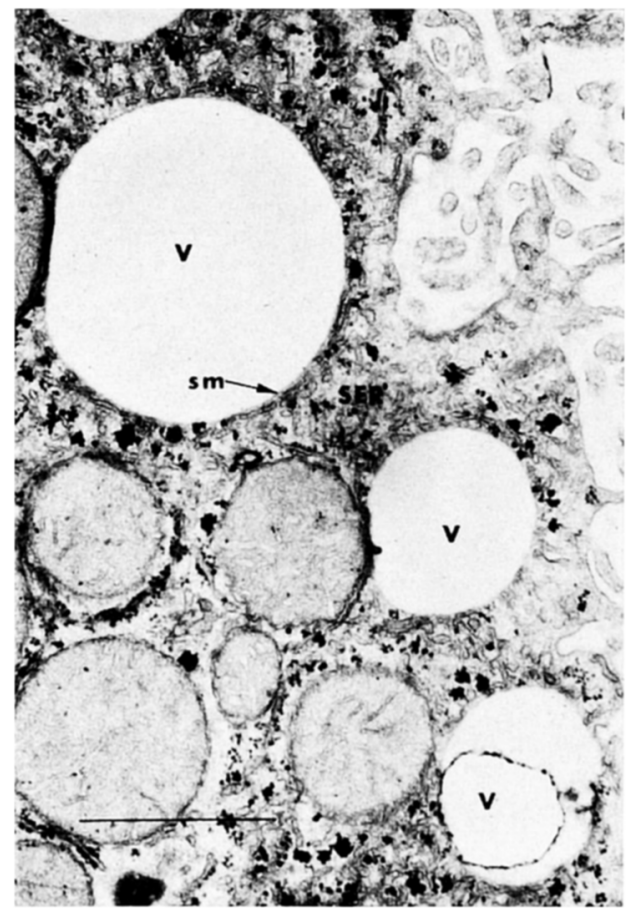

Fig. 10. Electronmicrograph of hepatocyte from a rat given $500 \mathrm{mg} \mathrm{DEA} / \mathrm{kg}$ body weight and killed $4 \mathrm{hr}$ later, showing smooth endoplasmic reticulum (SER) around vacuole (V) with stacking of membranes (sm). $\times 35,500$. 


\section{$00-00000-10-$}

$\begin{array}{llllllllllllllll}\text { C } & C & C & C & 500 & 500 & 500 & 500 & 100 & 100 & 100 & 100\end{array}$

Fig. 11. LDH zymogram from rats killed $4 \mathrm{hr}$ after DEA administration. The dose (in $\mathrm{mg} / \mathrm{kg}$ ) is indicated at the bottom of each channel. Control rats are indicated by the letter C. Rats given $500 \mathrm{mg} / \mathrm{kg}$ have an abnormal isoenzyme pattern. The elevation in the $\mathrm{LDH}-5$ band activity may be due entirely or in part to liver damage. The damaged tissue responsible for the unequal increases in bands 1 and 2 is unknown.

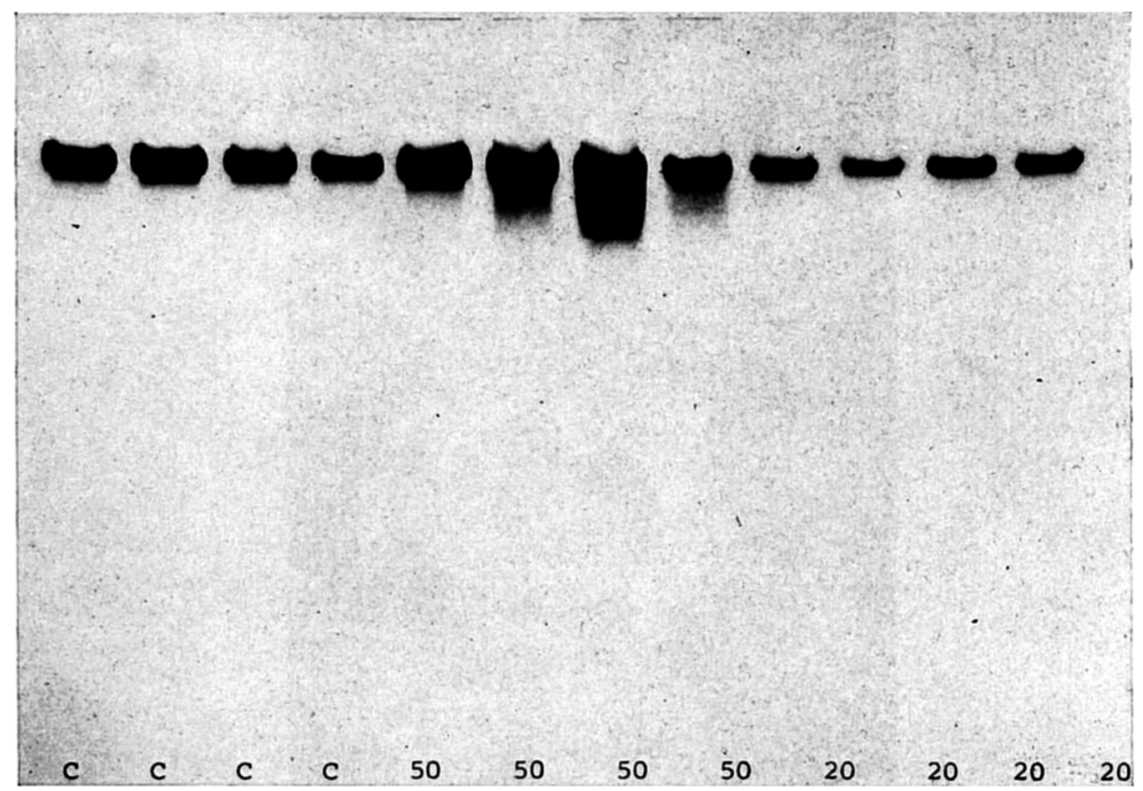

FIG. 12. LDH zymogram from rats killed $24 \mathrm{hr}$ after TA administration. The dose (in $\mathrm{mg} / \mathrm{kg}$ ) is indicated at the bottom of each channel. Control rats are indicated by the letter C. A broadening of LDH-5 band, suggesting liver damage, is seen in rats given $50 \mathrm{mg} / \mathrm{kg}$. 


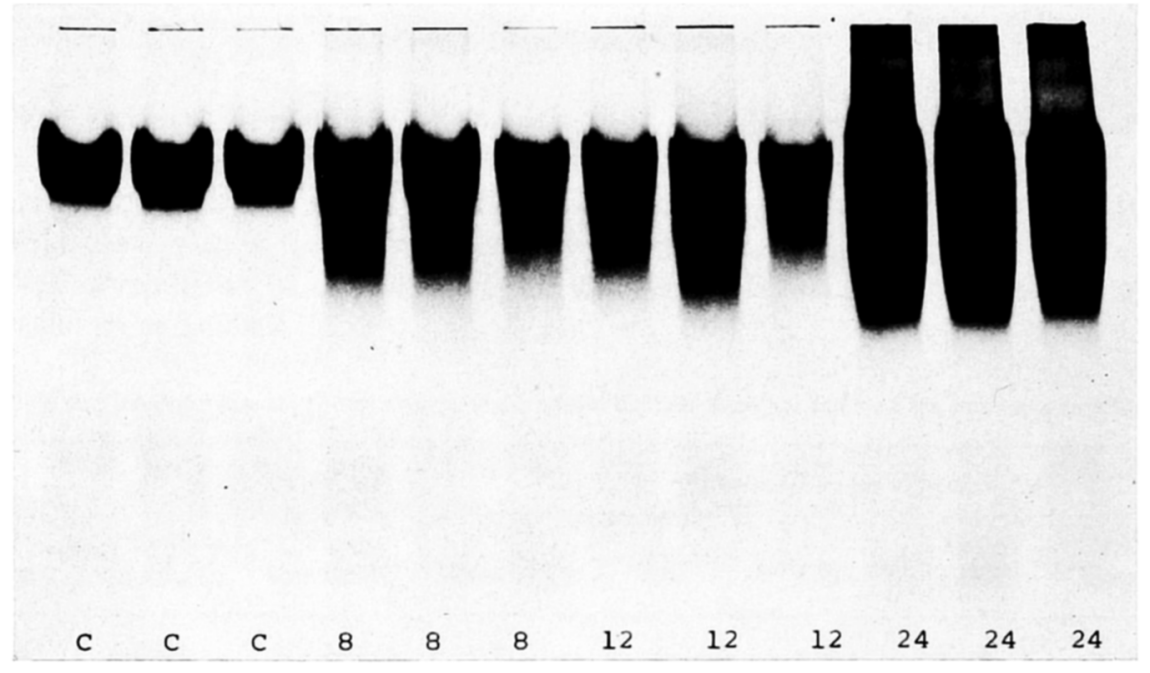

FIG. 13. LDH zymogram from rats given $200 \mathrm{mg} \mathrm{TA} / \mathrm{kg}$. The killing times (hr) are indicated at the bottom of each channel. Control rats are indicated by the letter $\mathrm{C}$. Early liver damage is suggested by the broadening of the LDH-5 band at 8 and $12 \mathrm{hr}$ and is particularly marked at $24 \mathrm{hr}$.

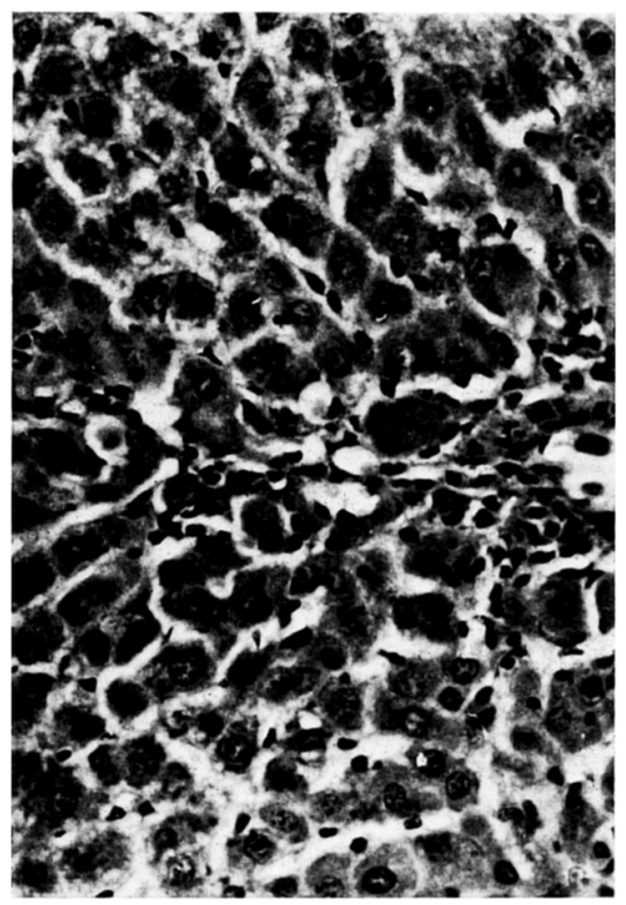

Fig. 14. Photomicrograph of liver from a rat given $200 \mathrm{mg} \mathrm{TA} / \mathrm{kg}$ and killed $72 \mathrm{hr}$ later. A few regenerative and degenerative changes, necrotic liver cells and inflammatory cells are seen, nuclei are enlarged and chromatin is clumped. Haematoxylin and eosin $\times 445$. 
enzymes had returned to normal. Regenerative and degenerative changes coexisted and necrotic liver cells were observed in these 72-hr sections (Fig. 14). Degeneration of renal tubular epithelium was seen at 24,48 and $72 \mathrm{hr}$ after TA treatment, but no evidence of kidney damage was seen in the isozyme patterns at any time.

An overall comparison of the sensitivity of the various criteria used to measure organ damage is shown in Table 2.

Table 2. The comparative sensitivity of enzyme and morphological changes induced by various compounds

\begin{tabular}{|c|c|c|c|c|c|c|c|}
\hline \multirow[b]{2}{*}{ Compound } & \multirow[b]{2}{*}{$\begin{array}{c}\text { Dose } \\
(\mathrm{mg} / \mathrm{kg})^{*}\end{array}$} & \multirow{2}{*}{$\begin{array}{c}\text { Time of } \\
\text { sacrifice } \\
\text { (hr after } \\
\text { treatment) }\end{array}$} & \multicolumn{5}{|c|}{ Degree of response $(0-4)$ as indicated by } \\
\hline & & & Histology $\dagger$ & EM & GOT & $\begin{array}{l}\text { Total } \\
\text { LDH }\end{array}$ & $\begin{array}{l}\text { LDH } \\
\text { isozymes }\end{array}$ \\
\hline $\mathrm{CCl}_{4}$ & $\begin{array}{l}0.03 \\
0.06 \\
0 \cdot 10 \\
0 \cdot 20\end{array}$ & $\begin{array}{l}24 \\
24 \\
24 \\
24\end{array}$ & $\begin{array}{l}1 \\
2 \\
3 \\
4\end{array}$ & $\begin{array}{l}1 \\
2 \\
- \\
-\end{array}$ & $\begin{array}{l}0 \\
0 \\
1 \\
2\end{array}$ & $\begin{array}{l}0 \\
0 \\
0 \\
1\end{array}$ & $\begin{array}{l}0 \\
0 \\
0 \\
1\end{array}$ \\
\hline $\mathrm{HgCl}_{2}$ & $\begin{array}{l}0.1 \\
0.5 \\
2 \cdot 0\end{array}$ & $\begin{array}{l}24 \\
24 \\
24\end{array}$ & $\begin{array}{l}3 \\
4 \\
4\end{array}$ & - & $\begin{array}{l}0 \\
0 \\
0\end{array}$ & $\begin{array}{l}0 \\
0 \\
1\end{array}$ & $\begin{array}{l}0 \\
0 \\
2\end{array}$ \\
\hline DEA & $\begin{array}{l}100 \\
500\end{array}$ & $\begin{array}{l}4 \\
24 \\
4 \\
24\end{array}$ & $\begin{array}{l}1 \\
2 \\
2 \\
3\end{array}$ & $\frac{1}{2}$ & $\begin{array}{l}0 \\
0 \\
1 \\
1\end{array}$ & $\begin{array}{l}0 \\
0 \\
1 \\
1\end{array}$ & $\begin{array}{l}0 \\
0 \\
1 \\
1\end{array}$ \\
\hline TA & $\begin{array}{l}20 \\
50 \\
200\end{array}$ & $\begin{array}{l}24 \\
24 \\
1 \\
2 \\
4 \\
8 \\
12 \\
24 \\
48 \\
72\end{array}$ & $\begin{array}{l}2 \\
3 \\
0 \\
0 \\
0 \\
2 \\
3 \\
4 \\
4 \\
4\end{array}$ & $\begin{array}{l}- \\
- \\
- \\
- \\
- \\
- \\
-\end{array}$ & $\begin{array}{l}0 \\
2 \\
- \\
- \\
- \\
- \\
- \\
-\end{array}$ & $\begin{array}{l}0 \\
1 \\
0 \\
0 \\
0 \\
0 \\
0 \\
3 \\
0 \\
0\end{array}$ & $\begin{array}{l}0 \\
1 \\
0 \\
0 \\
0 \\
1 \\
2 \\
4 \\
1 \\
0\end{array}$ \\
\hline
\end{tabular}

*Doses of $\mathrm{CCl}_{4}$ are expressed in $\mathrm{ml} / \mathrm{kg}$.

†The grading scale is as follows:

0 -No observable changes.

1-Minimal cloudy swelling hydropic change and loss of cytoplasmic basophilia.

2 \& 3-Degrees of degenerative change between minimal (1) and marked (4).

4-Marked degenerative change with numerous necrotic cells in affected areas.

\section{DISCUSSION}

The response of cells to the injurious agents used in these studies represents a varied range of toxic effects. Slater (1966) suggests that $\mathrm{CCl}_{4}$ must be "activated" to a free radical form by interaction with homolytic processes normally present in the endoplasmic reticulum and mitochondria. These highly reactive free radicals then interact with the neighbouring membrane material causing profound alterations in morphology and function. Although the difficulty of translating the complex processes involved in $\mathrm{CCl}_{4}$ toxicity into a single biochemical event has been pointed out (Alpers, Solin \& Isselbacher, 1968), $\mathrm{CCl}_{4}$ may 
exert its effect by the peroxidative decomposition of structural lipids of cytoplasmic membranes (Recknagel, 1967; Slater, 1966). The release of GOT (Gabrieli \& Orfanos, 1968) and lysosomal enzymes (Alpers \& Isselbacher, 1967) have been studied after the damage of cell organelles by $\mathrm{CCl}_{4}$. These investigations consider the role of lipid peroxidation in the pathogenesis of $\mathrm{CCl}_{4}$-induced liver injury. However, Cawthorne, Bunyan, Sennitt, Green \& Grasso (1970) discuss the lipid-peroxidation theory and point out evidence suggesting that a single pro-oxidant mechanism is not causally involved in $\mathrm{CCl}_{4}$ toxicity.

In the present study, dosages as small as $0.03 \mathrm{ml} \mathrm{CCl}_{4} / \mathrm{kg}$ resulted in detectable histopathological changes and swelling of the rough endoplasmic reticulum as viewed by electron microscopy. These early liver changes were not detectable by measurement of serum enzyme levels $24 \mathrm{hr}$ after dosing. At a dose of $0 \cdot 10 \mathrm{mg} \mathrm{CCl} / \mathrm{kg}$, elevations in serum GOT levels were detectable, but at this dosage liver necrosis was quite prominent.

Norseth (1968), in studies of the intracellular distribution of inorganic mercury in rat liver, pointed out that the proportion of mercury in the different populations of cellular particles changed with time after a single injection. However, the concentration in the lysosomes appeared to be the most stable over a 4-day period and Norseth (1968) suggested the possibility of primary lysosomal damage from inorganic mercury. The effect on renal tubular epithelium noted in the present study is consistent with the report of Prescott \& Ansari (1969), who concluded that repeated doses of $0.1 \mathrm{mg} \mathrm{HgCl} / \mathrm{kg}$ did not cause tubular necrosis. Marked necrosis occurred, however, following a dose of $0.5 \mathrm{mg} / \mathrm{kg}$.

The mechanism by which DEA exerts its toxicity is unknown at present. However, Artom, Cornatzer \& Crowder (1949) and Artom, Lofland \& Oates (1958) have demonstrated its incorporation into liver phospholipids. With chronic exposure to DEA, a progressive decrease in choline-containing phospholipids and an increase in non-choline-containing phospholipids was observed. On the basis of these observations, it was suggested by Artom et al. (1949 \& 1958) that DEA may compete with ethanolamine and/or choline for incorporation into tissue phospholipids, with subsequent alteration in structure and function of the phospholipids necessary for normal membrane integrity. Hruban, Swift \& Slesers (1965) have also demonstrated by EM that DEA causes marked disruption of endoplasmic reticulum with release of ribosomes. Studies currently underway in this laboratory (University of Michigan) demonstrate that DEA is a potent inhibitor of microsomalenzyme systems involved in the metabolism of foreign compounds (Foster, Hartung \& Cornish, 1971).

Thioacetamide inhibits the migration of RNA (labelled with tritiated cytidine) from the nucleus and particularly from the nucleolus to the cytoplasm in rat tissue (Stöcker \& Yokoyama, 1966). TA also appears to inhibit the "flow" of RNA or RNA-containing constituents in the nucleolus (Steel \& Busch, 1966). These alterations in nuclei and nucleoli are the result of altered nucleic-acid metabolism (Steel \& Okamura, 1964) and as such would not be expected to be associated with release of enzyme into the serum. However, TA was also shown to induce cellular injury by direct effects on the cell membrane, mitochondria and endoplasmic reticulum (Gallagher, Gupta, Judah \& Rees, 1956) with subsequent increases in serum enzyme levels. TA exerts a somewhat similar but less pronounced effect on the kidney (Kleinfeld, 1957; Hruban, Gradman, Slesers \& Lubran, 1966).

It is apparent from the present studies that morphological damage generally occurs at dosage levels considerably below those necessary to induce detectable serum enzyme alterations. Generally, advanced degenerative change, including necrosis, had occurred in both the liver and the kidney before altered enzyme levels were seen. An exception to this was 
seen with $500 \mathrm{mg} D E A / \mathrm{kg}$, hydropic change being associated with marked serum enzyme increases. However, these increases were noted very early ( $4 \mathrm{hr}$ after injection) and the hydropic change was generalized, all zones of the liver being equally affected. At $72 \mathrm{hr}$ after administration of TA, necrotic cells were being phagocytized and their content of enzymes would, in all probability, have long since passed from the blood stream.

Although GOT was a more sensitive indicator of organ damage than LDH, it did not provide isozyme patterns which could identify the specific target organ. LDH was relatively insensitive in detecting renal tubular damage, and fairly extensive histological damage was evident before serum LDH levels were elevated.

Control values for serum LDH varied considerably from group to group. The data in this report are from studies conducted over a 2-yr period. During this time the level of LDH gradually increased in the strain of rats used, although the animals were all obtained from the same source. The increase in LDH activity in untreated rats seems to reside entirely in band 5. Elevations in serum LDH due to viral infections in mice are recognized and it is possible that an analogous virus exists for rats. However, serum GOT did not change, nor was there any histological evidence of liver damage in these animals. Because of these variations in $\mathrm{LDH}$ values, it is evident that data from each group of animals must be compared with the appropriate control group.

It would appear that the mechanism by which a compound produces its toxic effect determines, to a large extent, the response of serum enzyme levels to that toxicant. The classical hepatotoxic and nephrotoxic compounds, $\mathrm{CCl}_{4}$ and $\mathrm{HgCl}_{2}$, respectively, produce marked histological changes prior to the elevation of serum enzyme levels. DEA produces a rise in serum enzymes simultaneously with hydropic degeneration and prior to necrotic changes. Thus different toxicants result in different relationships between histological damage and serum enzyme levels. It becomes apparent that there is insufficient knowledge of the mechanisms by which most compounds produce their toxic effect to predict reliably the relationship between histological effects and serum enzyme levels. Studies at present underway (FDD) suggest that other serum enzymes, such as sorbitol dehydrogenase, may be more sensitive indicators of organ damage than those used in this study. At this point, however, it appears that, in general, serum enzyme levels and isozyme patterns are an important supplement to, and not a substitute for, histopathological examination of tissues during toxicological investigations.

Acknowledgement-We are indebted to Mrs. Roberta K. Brabec for her skilful assistance in the preparation of tissues for electron microscopy.

\section{REFERENCES}

Alpers, D. H. \& Isselbacher, K. J. (1967). The effect of carbon tetrachloride on rat-liver lysosomes. Biochim. biophys. Acta 137, 33.

Alpers, D. H., Solin, M. \& Isselbacher, K. J. (1968). The role of lipid peroxidation in the pathogenesis of carbon tetrachloride-induced liver injury. Molec. Pharmacol. 4, 566.

Artom, C., Cornatzer, W. \& Crowder, M. (1949). The action of an analogue of ethanolamine (diethanolamine) on the formation of liver phospholipids. J. biol. Chem. 180, 495.

Artom, C., Lofland, H. B. \& Oates, J. A., Jr. (1958). In vivo incorporation of diethanolamine into liver lipids. J. biol. Chem. 233, 833.

Balazs, T., Murray, T. K., McLaughlan, J. M. \& Grice, H. C. (1961). Hepatic tests in toxicity studies on rats. Toxic. appl. Pharmac. 3, 71 .

Cawthorne, M. A., Bunyan, J., Sennitt, M. V., Green, J. \& Grasso, P. (1970). Vitamin E and hepatotoxic agents. 3.Vitamin $\mathrm{E}$, synthetic antioxidants and carbon tetrachloride toxicity in the rat. Br.J. Nutr. 24, 357. 
Cornish, H. H., Barth, Mary L. \& Dodson, V. N. (1970). Isozyme profiles and protein patterns in specific organ damage. Toxic. appl. Pharmac. 16, 411.

Foster, G. V., Hartung, R. \& Cornish, H. H. (1971). Inhibition of hepatic microsomal enzymes by Nsubstituted ethanolamines. Toxic. appl. Pharmac. 19. In press.

Gabrieli, E. R. \& Orfanos, A. (1968). Effect of carbon tetrachloride on serum glutamic-oxalacetic transaminase isoenzymes. Proc. Soc. exp. Biol. Med. 127, 766.

Gallagher, C. H., Gupta, D. N., Judah, J. D. \& Rees, K. R. (1956). Biochemical changes in liver in acute thioacetamide intoxication. J. Path. Bact. 72, 193.

Hruban, Z., Gradman, W., Slesers, A. \& Lubran, M. (1966). Toxicity of thioacetamide. Lab. Invest. 15, 1748.

Hruban, Z., Swift, H. \& Slesers, A. (1965). Effect of triparanol and diethanolamine on the fine structure of hepatocytes and pancreatic acinar cells. Lab. Invest. 14, 1652.

Karmen, A. (1955). A note on the spectrophotometric assay of glutamic-oxalacetic transaminase in human blood serum. J. clin. Invest. 34, 131.

Klaassen, C. D. \& Plaa, G. L. (1967). Relative effects of various chlorinated hydrocarbons on liver and kidney function in dogs. Toxic. appl. Pharmac. 10, 119.

Kleinfeld, Ruth G. (1957). Early changes in rat liver and kidney cells induced by thioacetamide. Cancer Res. 17,954 .

Koch-Weser, D., Farber, E. \& Popper, H. (1951). Fatty liver with and without necrosis. Histological and biochemical investigations. Archs Path. 51, 498.

Norseth, T. (1968). The intracellular distribution of mercury in rat liver after a single injection of mercuric chloride. Biochem. Pharmac. 17, 581.

Prescott, L. F. \& Ansari, Shameen (1969). The effects of repeated administration of mercuric chloride on exfoliation of renal tubular cells and urinary glutamic-oxaloacetic transaminase activity in the rat. Toxic. appl. Pharmac. 14, 97.

Recknagel, R. O. (1967). Carbon tetrachloride hepatotoxicity. Pharmac. Rev. 19, 145.

Reeves, A. L., Busby, Elizabeth K. \& Scotti, Lucille (1966). Gel electrophoresis in the study of pneumoconioses. Am. ind. Hyg. Ass. J. 27, 278.

Slater, T. F. (1966). Necrogenic action of carbon tetrachloride in the rat: A speculative mechanism based on activation. Nature, Lond. 209, 36.

Steel, W. J. \& Busch, H. (1966). Increased content of high molecular weight RNA fractions in nuclei and nucleoli of livers of thioacetamide-treated rats. Biochim. biophys. Acta 119, 501.

Steel, W. J. \& Okamura, N. (1964). Effect of thioacetamide (TA) on biosynthesis of nuclear RNA fractions in rat liver. Fedn Proc. Fedn Am. Socs exp. Biol. 23, 281.

Stöcker, E. u. Yokoyama, T. (1966). Autoradiographische Studien zum Einfluss von Thioacetamid auf die RNS-Migration und DNS-synthese verschiedener parenchymatöser Zellen der Ratte. Beitr. path. Anat. 134, 1 .

Wróblewski, F. \& LaDue, J. S. (1955). Lactic dehydrogenase activity in blood. Proc. Soc. exp. Biol. Med. $90,120$.

\title{
Corrélation entre les enzymes du sérum, les profils d'isoenzymes et les lésions organiques dépistables par l'examen histologique .
}

\begin{abstract}
Résumé-Les taux d'enzymes et les profils d'isoenzymes du sérum ont été utilisés comme mesures de la réaction hépatotoxique au tétrachlorure de carbone, au chlorure mercurique, à la diéthanolamine et à la thioacétamide. La sensibilité de ces mensurations a été comparée avec le degré de détérioration morphologique du foie ou du rein, tel qu'il est reconnu par microscopie optique ou électronique. Des détériorations morphologiques ont été identifiées à des doses considérablement plus faibles que celles qui étaient nécessaires pour provoquer des altérations dépistables des enzymes. Le foie comme le rein présentaient en général des modifications dégénératives avancées, dont de la nécrose, bien avant que l'on ne constate des altérations des enzymes.
\end{abstract}




\section{Korrelation zwischen Serumenzym- und -isozymverteilungen und histologisch feststellbaren Organschäden}

Zusammenfassung-Serumenzymkonzentrationen und Serumisozymprofile wurden als Mass der hepatotoxischen Reaktion auf Tetrachlorkohlenstoff, Quecksilber(II)-chlorid, Diäthanolamin und Thioacetamid benutzt. Die Empfindlichkeit dieser Messungen wurde mit dem Grad morphologischer Schäden der Leber oder der Nieren in licht- oder elektronenmikroskopischer Untersuchung verglichen. Morphologische Schäden traten bei Dosierungen auf, die beträchtlich unter denjenigen lagen, die feststellbare Enzymänderungen einleiteten. Im allgemeinen waren schon fortgeschrittene degenerative Veränderungen einschliesslich Nekrose in der Leber und in den Nieren eingetreten, ehe enzymatische Veränderungen beobachtet werden konnten. 